\title{
The Determinant for Choice of Delivery Method in Indonesia 2018
}

\author{
Hadi Ashar', Ina Kusrini ${ }^{1}$, Ika Puspita Asturiningtyas', ${ }^{1}$ Noviati Fuada ${ }^{1}$ \\ dan Arita Murwani ${ }^{2}$, ${ }^{1}$ Health Research and Development Magelang, ${ }^{2}$ Stikes \\ Surya Global Yogyakarta, Email: hdi.gaki@gmail.com
}

\begin{abstract}
Pregnancy complications become one of the considerations in choosing a delivery method. Choosing the appropriate delivery method will save the mother and baby from mortality threat. This analysis is aimed to know how the relationship between the maternal characteristics with pregnancy complication and the choice of delivery method, such as caesarean section surgery procedure. This study is an advanced analysis of Riskesdas data 2018, using married women of childbearing age between $10-54$ years old as the population, while the sample is whom they gave birth and became the Riskesdas sample in 2018 as much as 78,736. The chosen variables for this study are the maternal characteristics and the pregnancy complications as the independent variables, and the choice of delivery method as the dependent variable. This study shows that the maternal characteristics such as age, education, occupation and pregnancy complications also the source of labor cost related to the choice of delivery method with p-value 0.00 . Mothers who have a pregnancy complication tend to do a caesarean section delivery process 9.4 bigger than who do not have any. Based on the result, it can be concluded that the maternal characteristics such as age, education, occupation, source of labor cost and the pregnancy complication are related to the choice of the delivery method in Indonesia in 2018.
\end{abstract}

Key words: pregnancy complication, delivery method, caesarean section

\section{INTRODUCTION}

A pregnancy complication is a health condition during pregnancy that can happen to the normal pregnancy even to the risky one. The high risk pregnancy is related with some problems that can affect a marital welfare and also mother and child's health even mortality(Mirzakhani et al., 2020). Some kinds of pregnancy complications happened, with various levels of problem, cause the disruption in the delivery process(Kementerian Kesehatan RI, 2014). The percentage of complications to a risky pregnancy has considerably 
bigger than on the free-risk pregnancy(Juharni et al., 2012). These can be more severe if there is no monitoring or early detection during Antenatal Care(Adamu et al., 2018). The undetected complications can make health problem and imply to the delivery process(WHO Statement on Cesarean Section Rates, 2015), also effect the choice of delivery method(Direktorat Bina Pelayanan Medik Dasar Departemen Kesehatan RI, 2010).

The delivery process is a critical period for a pregnant woman. Mothers are very dependent on information and pregnancy health issues, when making decisions about the way of delivery they want, which normal delivery (vaginal) or sectio cesarean(Roudsari et al., 2015). Health services provided, such as prenatal care, delivery methods and postnatal care, have a role in determining delivery methods, as well as reducing maternal morbidity and mortality(Dhakal et al., 2018). Efforts to increase the scope of services must be carried out in the community and in improving services at the Primary Health Care Fasilities. Pregnancy complications can be a risk factor to the maternal and child's mortality. The suitable choice of delivery method can minimize the risk for both mother and baby born. This risk can be fatal, which can cause death to both mother and child, and directly contribute to the Number of Maternal and Child Mortality(Kementerian Kesehatan RI, 2014). World Health Organization (WHO) stated that the maternal mortalities happen either during pregnancy, or labor period until 42 days after the process with directly or indirectly caused by either the pregnancy or delivery process(WHO Statement on Cesarean Section Rates, 2015).

Delivery method is a process of expelling the fetus from the womb, naturally through vaginal delivery as well as surgery with an incision in the abdomen/ caesarean section. These delivery processes mostly conduct in the health service facilities that fill the health service standard, and are helped by trained medical staffs(Direktorat Bina Pelayanan Medik Dasar Departemen Kesehatan RI, 2010). Data shows that the proportion of delivery place in the health service facilities is $79 \%$ with the highest qualification of delivery assistant as much as 93.1\% (NIHRD, 2018). These data are followed by some trends in choosing the delivery method with caesarean section. In the last decade, the number of caesarean section is getting higher(Alam \& Arora, 1995) .The data from Risdesdas 2010 shows 15.3\% (Balitbangkes, 2010), from Indonesia Demographic and Health Survey (SDKI) in 2017 shows a higher number of caesarian section, which is $16.4 \%$ (BPS, 2017), and from Riskesdas 2018 shows $17.46 \%$ (NIHRD, 2018). These numbers are bigger than the number suggested by WHO as much as $10-15 \%$ (WHO Statement on Cesarean Section Rates, 2015)'(Suryati, 2013). Sectio caesarian surgery is an effective intervention to save the lives of mothers and babies, however, the rate of sectio caesarean which is higher than $10 \%$ at the population level disassociated with a decrease in maternal and infant mortality(Ye et al., 2016). The high number of caesarean section is not only happened in Indonesia. Sectio caesarea around the world has increased to an unprecedented level, although there are gaps in some countries due to the existing resources and facilities(Betrán et al., 2016). Sectio caesarea that is performed needs to be reviewed to reduce health costs and risks to the mother and fetus(Souza et al., 2010). The prevalence of sectio caesarea is very high worldwide, indicating that there are 
other factors affecting this condition(Vega et al., 2015). Based on the result of statistical review, it is stated that in some countries, there is a propensity of delivery method by caesarean section as trends. It shows that there are 69 from 137 countries with high number of caesarean section above $15 \%$ (Gibbons et al., 2010). While WHO stated that caesarean section procedures cannot show the significant decreasing number of mother and child mortality(WHO Statement on Cesarean Section Rates, 2015), the same thing also proves that based on the results of a systematic review on the level of sectio caesarea within the WHO standard threshold, there is no relationship between mortality and increasing caesarean section above the standard that does not reduce maternal and infant mortality(Betran et al., 2015).

This advanced analysis is purposed to know the relationship between the maternal characteristics, pregnancy complications and the choice of delivery method, such as caesarean section surgery procedures.

\section{METHODS}

\section{Population and Sample}

The source of the data taken from Indonesian Basic Health Survey (Riskesdas) 2018, a Cross Sectional study in 34 provinces in Indonesia with household analysis units. The 2018 Riskesdas research protocol was approved by the ethics commission of the National Institute of Health Research and Development (NIHRD), Ministry of Health Indonesia. All of the subjetcs had signed an informed consent. The population in this research is the married women with childbearing age $10-54$ years old, while the sample is women aged $10-54$ years old who fill the inclusion and exclusion criteria. The inclusion criteria is women aged 10 - 54 years old who have given birth and became the sample in Riskesdas 2018 while the exclusion criteria is the sample which does not have a complete data. The total sample is 78,736 samples. These are drawn with Multistage Sampling Method with census block as the cluster.

\section{Research Variable}

The variables taken in this article are the maternal characteristics and pregnancy complications as the independent variable; and choosing the delivery method as the dependent variable. The maternal characteristics include age, education, and occupation. The pregnancy complications include transverse fetal position, bleeding, seizures, premature rupture of membrane, old labor, umbilical cord winding, placenta previa, retensio placenta and hypertension. The choices of delivery method are normal delivery, Caesarean Section, Vacuum, Forceps, Induction and others. Furthermore, those delivery methods are divided into Caesarean Section and vaginal delivery. 
International Journal of Innovation, Creativity and Change. www.ijicc.net

Volume 15, Issue 9, 2021

\section{Statistical Analysis}

Data is analyzed by using software licensed SPSS 21 owned by Health Research and Development Center Magelang after cleaning data. The univariate analysis was done to get the proportion data of the research respondent characteristics. The bivariate analysis was done to know the proportion of choosing the delivery methods based on the respondent characteristics using Chi-Square.Variables in the multivariate analysis were derived from variables with a p-value of $<0.25$ in the bivariate analysis. The multivariate analysis is done to see the determinants that affects the choice of delivery methods.

\section{RESULT}

Table 1. Maternal Characteristics

\begin{tabular}{|c|c|c|c|}
\hline Variables & Category & Freq & $\%$ \\
\hline \multirow[t]{2}{*}{ Age } & Low risk (20-35 years old) & 58.368 & 74.13 \\
\hline & High risk $(<20$ y.o. / >35 y.o $)$ & 20.368 & 25.87 \\
\hline \multirow[t]{2}{*}{ Education } & Primary (SD - SLTP) & 42.260 & 53.67 \\
\hline & Secondary (SLTA - PT) & 36.476 & 46.33 \\
\hline \multirow[t]{10}{*}{ Job status } & Unemployment & 46.404 & 58.94 \\
\hline & In school & 550 & 0.70 \\
\hline & Civil servant/ Army/ Police & & \\
\hline & Officer/ BUMN/ BUMD & 1.964 & 2.49 \\
\hline & Private Staff & 6.460 & 8.20 \\
\hline & Entrepreneur & 7.441 & 9.45 \\
\hline & Farmer & 6.503 & 8.26 \\
\hline & Fisherman & 85 & 0.11 \\
\hline & Laborer/ driver/ housemaid & 2.968 & 3.77 \\
\hline & Others & 6.360 & 8.08 \\
\hline \multirow[t]{10}{*}{ Pregnancy complications } & Transverse fetal position & 2.434 & 3.09 \\
\hline & Bleeding & 1.858 & 2.36 \\
\hline & Seizures & 100 & 0.13 \\
\hline & Premature rupture of membrane, & 4.000 & 5.08 \\
\hline & Old labor & 2.656 & 3.37 \\
\hline & Umbilical cord winding & 1.655 & 2.10 \\
\hline & Placenta previa & 433 & 0.55 \\
\hline & Retensio placenta & 453 & 0.58 \\
\hline & Hypertension & 1.566 & 1.99 \\
\hline & No complications & 60.450 & 76.78 \\
\hline \multirow[t]{3}{*}{ Delivery Methods } & Normal & 64.133 & 81.5 \\
\hline & Caesarean Section & 13.890 & 17.5 \\
\hline & Vacuum & 543 & 0.7 \\
\hline
\end{tabular}


International Journal of Innovation, Creativity and Change. www.ijicc.net

Volume 15, Issue 9, 2021

\begin{tabular}{rlrr}
\hline & Forceps & 53 & 0.1 \\
Induction & 72 & 0.1 \\
Others & 55 & 0.1 \\
Source of labor cost & 27.492 & 34.92 \\
& BPJS/KIS & 833 & 1.06 \\
& Private insurance & 1.566 & 1.99 \\
Office expenses & 235 & 0.32 \\
Other person expenses & 42.756 & 54.30 \\
& Self-expenses & 2.799 & 3.55 \\
& Jampersal & 958 & 1.22 \\
& Jamperda & 2.098 & 2.66 \\
\hline
\end{tabular}

Table 1 shows the respondent characteristics. Maternal characteristics based on the age group shows that there is less than a quarter of pregnant women who are high risk of pregnancy. More than half mothers only took a primary school and unemployed. Most of them have no complications during birthing (79.8\%) but there were some complications that happen $20 \%$ of mothers. About $17.5 \%$ of mothers done caesarean section as a delivery method, while most of them used slef-expenses as source of labor cost.

Table 2 Result of logistic regression test to the maternal characteristic with delivery method

\begin{tabular}{|c|c|c|c|c|c|c|}
\hline \multirow{3}{*}{ Variables } & \multicolumn{4}{|c|}{ delivery method } & \multirow{3}{*}{$\begin{array}{c}P \text { - } \\
\text { value }\end{array}$} & \multirow{3}{*}{ OR } \\
\hline & \multicolumn{2}{|c|}{ Vaginal } & \multicolumn{2}{|c|}{$\begin{array}{c}\text { Caesarean } \\
\text { Section }\end{array}$} & & \\
\hline & $\mathrm{N}$ & $\%$ & $\mathrm{~N}$ & $\%$ & & \\
\hline Age & & & & & 0.000 & 1.410 \\
\hline Normal & 48.591 & 83.2 & 9.777 & 16.8 & & \\
\hline High risk & 16.255 & 79.8 & 4.113 & 20.2 & & \\
\hline Education & & & & & 0.000 & 2.297 \\
\hline Primary & 37.287 & 88.2 & 4.973 & 11.8 & & \\
\hline Secondary & 27.559 & 75.6 & 8.917 & 24.4 & & \\
\hline Job status & & & & & 0.000 & 1.423 \\
\hline Casual & 58.870 & 83.7 & 11.442 & 16.3 & & \\
\hline Permanent & 5.976 & 70.9 & 2.448 & 29.1 & & \\
\hline Pregnancy Complications & & & & & 0.000 & 9.480 \\
\hline No complications & 55.370 & 91.6 & 5.080 & 8.4 & & \\
\hline With complications & 9.476 & 51.8 & 8.810 & 48.2 & & \\
\hline Source of funds & & & & & 0.000 & 2.972 \\
\hline Self-fund/ other people/ no expenses & 40.772 & 90.4 & 4.317 & 9.6 & & \\
\hline Insurance/ Institutions & 24.074 & 71.5 & 9.573 & 28.5 & & \\
\hline
\end{tabular}


Table 2 in this study shows that that maternal characteristic based on the age group have significant relationship to the choice of delivery methods. Mothers who belong to the highrisk pregnancy group will choose caesarean section procedures 1.4 higher than those who do not have high risk pregnancy. This study also shows that education and occupation are related to the delivery methods. Mother who has high education and permanent job tends to do a caesarian section procedure. Mothers with complications showed tend to do caesarean section as delivery method $(\mathrm{OR}=9.840)$. Mothers who has insurance or source of funds form institution also tend to do caesarean section $(\mathrm{OR}=2.972)$.

\section{DISCUSSION}

Mothers in the high-risk group showed that have a high risk for caesarean section. This risk group has two categories which are the group of mothers who is too young (younger than 20 years old) and too old (older than 35 years old). Mothers with these risks are the vulnerable groups that have high risk of pregnancy complication. The result of the previous research held in the countryside in one regency in Central Java, Indonesia shows that mothers who has high risk of pregnancy are 33\% (Latifah et al., 2020). The group of mothers younger than 20 years old has risk because the lack of readiness from health aspects, women reproduction organs medically unready to have pregnancy, emotional mental readiness, also education and economic status. A study shows that delivery to a mother younger than 20 years old proven to contribute towards the high number of neonatal, baby and toddler mortality(Badan Pusat Statistik, 2012). In the age group of older than 35 years old, the organs have decreased, thus it is medically not suggested.

This study also shows that education and occupation are related to the delivery methods. Mother who has high education and permanent job tends to do a caesarian section procedure compared with mother having low education and casual job. The advanced research study from Riskesdas 2018 that mothers with primary education have 1.4 chance bigger to have risks from pregnancy complications(Sari et al., 2015). Besides that, these complications may be happened more to the group of mother with low education level and economic level, also having trouble in accessing to the health facility averagely people living in countryside who tend to have low education(Latifah et al., 2020).

There are some interesting things in Table 1 which there is a slight difference as much as $4.27 \%$ (3,683 mothers) with the pregnancy complication still can have normal delivery. The efforts that mothers done together with the medical staffs in handling the delivery resulting a good decision by decreasing the risk level of delivery, in this case is caesarian section procedures. It directly increases the delivery scope in health service facilities and decreases the high number of caesarian section. The right decision made by the mother can give impact to the comfort and safety during the delivery process. The maternal decision of delivery has some aspects which are culture, social and psychological dimension(Roudsari et al., 2015). 
There are $23.33 \%$ mothers who have pregnancy complications with biggest rank to premature rupture of membrane, old labor, and transverse fetal position. Choosing the delivery methods is done by vaginal process or medical procedures. Table 2 also shows that there are numbers that can be an attention which there are $8.4 \%$ mothers who do not have pregnancy complications, do caesarian section procedures. This can be a question whether caesarian section procedures has been suited to the medical indication or not. The result of study logistic test as stated in table 2, that the pregnancy complications are related to the delivery methods. Mothers who have pregnancy complications tend to do caesarian section procedures 9.4 bigger than do not have pregnancy complications.

Mothes who have insurance or source of cost by institution ten to do caesarean section also. The labor cost still becomes an issues to access a labor in medical place due to the economic and lack of money as the factors(Pratiwi \& Basuki, 2016). The participation of mothers in health insurance programs will lighten the burden of the mothers when facing the delivery process. Government has facilitated the childbirth guarantee policy (jampersal) also health insurance for all (BPJS/KIS) to increase the easy access for mothers with the health facility.

Some methods are done by normal delivery or medical procedures. Choosing the delivery methods based on the previous research result shows that belief, culture, value and tradition significantly can affect to the individual attitude towards the choice of delivery methods(Roudsari et al., 2015). This study shows that caesarian section procedures is the first rank procedures with $17.5 \%$, other procedures like Vacuum, Forceps, and induction has small number $0.7 \%$ and $0.1 \%$. Sectio caesaria is one of the most frequently performed surgical procedures in the world, although various complications may occur and can be potentially serious if not performed with proper medical indications(Field \& Haloob, 2016), associated with an increased risk for both mother and child(Mylonas \& Friese, 2015),(Chhabra, 2015). Maternal mortality after caesarean section is three times higher than vaginal delivery(Kallianidis et al., 2018). The government, professional organizations, institutions, the public, must work together to reduce the suffering of mothers and children due to sectio caesaria operations that are not in accordance with medical indications(Chhabra, 2015).

The number of Caesarian Section procedures is getting higher, in 2010 there are $15.3 \%$ (Balitbangkes, 2010), in 2017 there are 16.4\% (Ashar \& Kusrini, 2020), these numbers are higher than WHO recommendation which is $10-15 \%$. Some factors affect to the high number of caesarian section procedures. Based on the advanced study for Indonesia Health Demography Survey in 2017, the high number of caesarian section procedures is influenced by the factor of maternal age, child's number, education, living place(Ashar \& Kusrini, 2020), anemia(Mulyawati et al., 2011), mother and child health status, pregnancy and labor complication, and complete antenatal care history(Sihombing et al., 2017). 
Table 2 shows the relationship between the health guarantee and insurance connected to the delivery methods. Mothers who have a health insurance will do caesarian section procedures 2.9 bigger than who do not have any health insurance.

\section{CONCLUSION}

The maternal characteristics such as age, education, source of labor cost and pregnancy complications are significantly related to the choice of delivery methods in Indonesia 2018.

\section{ACKNOWLEDGMENT}

Our sincere gratitude for data management team of the health research and development agency, the Indonesian Health MInisty, and the head of the Magelang health research and development center, who have provided the opportunity to use the data in this article.

\section{CONFLICT OF INTEREST}

None declared. 
International Journal of Innovation, Creativity and Change. www.ijicc.net

Volume 15, Issue 9, 2021

\section{REFERENCES}

Adamu, P. I., Adamu, M. O., \& Okagbue, H. I. (2018). Data in support of high rate of pregnancy related deaths in Maiduguri, Borno State, Northeast Nigeria. Data in Brief, 18, 409-414. https://doi.org/10.1016/j.dib.2018.03.038

Alam, M., \& Arora, R. (1995). Caesarean Section Changing Trends During Last Two Decades. Medical Journal Armed Forces India, 51(3), 183-185. https://doi.org/10.1016/s0377-1237(17)30962-0

Ashar, H., \& Kusrini, I. (2020). Determinant of the Increased Sectio Caesarea Labor Rates of Indonesia in 2017. Advances in Health Sciences Research, 22(Vol 22), 268-272.

Badan Pusat Statistik. (2012). Survei Demografi dan Kesehatan Indonesia 2012. In Badan pusat statistik. https://doi.org/10.1111/j.1471-0528.2007.01580.x

Balitbangkes. (2010). Riset Kesehatan Dasar 2010. https://doi.org/1 Desember 2013

Betran, A. P., Torloni, M. R., Zhang, J., Ye, J., Mikolajczyk, R., Deneux-Tharaux, C., Oladapo, O. T., Souza, J. P., Tunçalp, Ö., Vogel, J. P., \& Gülmezoglu, A. M. (2015). What is the Optimal Rate of Caesarean Section at Population Level? A Systematic Review of Ecologic Studies. Reproductive Health, 12(1). https://doi.org/10.1186/s12978-015-0043-6

Betrán, A. P., Ye, J., Moller, A. B., Zhang, J., Gülmezoglu, A. M., \& Torloni, M. R. (2016). The increasing trend in caesarean section rates: Global, regional and national estimates: 1990-2014. PLoS ONE, 11(2), 1-12. https://doi.org/10.1371/journal.pone.0148343

BPS. (2017). Survei Demografi dan Kesehatan.

Chhabra, S. (2015). Increasing Cesarean Births, Cause for Concern. International Journal of Gynecology, Obstetrics and Neonatal Care, 2(3), 13-19. https://doi.org/10.15379/2408-9761.2015.02.03.04

Dhakal, P., Shrestha, M., Baral, D., \& Pathak, S. (2018). Factors Affecting the Place of Delivery among Mothers Residing in Jhorahat VDC, Morang, Nepal. International Journal of Community Based Nursing and Midwifery, 6(1), 2-11. https://www.ncbi.nlm.nih.gov/pmc/articles/PMC5747568/

Direktorat Bina Pelayanan Medik Dasar Departemen Kesehatan RI. (2010). Pedoman pelayanan Antenatal.

Field, A., \& Haloob, R. (2016). Complications of caesarean section. The Obstetrician \& Gynaecologist, 18(4), 265-272. https://doi.org/10.1111/tog.12280

Gibbons, L., Belizán, J. M., Lauer, J. A., Betrán, A. P., Merialdi, M., \& Althabe, F. (2010). The Global Numbers and Costs of Additionally Needed and Unnecessary Caesarean Sections Performed per Year. In World Health Report (Vol. 30). https://www.who.int/healthsystems/topics/financing/healthreport/30C-sectioncosts.pdf

Juharni, S., Widarsa, T., Wirawan, D. N., Juharni, S., Widarsa, T., \& Wirawan, D. N. (2012). Faktor Risiko Kematian Ibu Sebagai Akibat Komplikasi Kehamilan , Persalinan dan Nifas di Kabupaten Bima tahun 2011 - 2012. In Magister Ilmu Kesehatan masyarakat Universitas Udayana (Vol. 1). 
International Journal of Innovation, Creativity and Change. www.ijicc.net

Volume 15, Issue 9, 2021

Kallianidis, A. F., Schutte, J. M., van Roosmalen, J., \& van den Akker, T. (2018). Maternal Mortality after Cesarean Section in the Netherlands. European Journal of Obstetrics and Gynecology and Reproductive Biology, 229, 148-152. https://doi.org/10.1016/j.ejogrb.2018.08.586

Kementerian Kesehatan RI. (2014). Situasi Kesehatan Ibu. In Pusat Data dan Informasi Kementrian Kesehatan

$R I$. www.depkes.go.id/resources/download/pusdatin/infodatin/infodatin-ibu.pdf

Latifah, L., Setiawati, N., Kartikasari, A., \& Kusmiati, E. (2020). Socio Demographic Characteristics Of Pregnant Women Who Are Experiencing Nausea Vomiting In Rural Areas Of Banyumas Regency. SHS Web of Conferences, 86, 01003. https://doi.org/10.1051/shsconf/20208601003

Mirzakhani, K., Khadivzadeh, T., Faridhosseini, F., \& Ebadi, A. (2020). Pregnant Women's Experiences of the Conditions Affecting Marital Well-Being in High-Risk Pregnancy: A qualitative study. International Journal of Community Based Nursing and Midwifery, 8(4), 345-357. https://doi.org/10.30476/ijcbnm.2020.85666.1285

Mulyawati, I., Azam, M., \& Ningrum, D. (2011). Faktor Tindakan Persalinan Operasi Sectio Caesarea. Jurnal Kesehatan Masyarakat, 7(1), 14-21. https://doi.org/10.15294/kemas.v7i1.1788

Mylonas, I., \& Friese, K. (2015). Indications for and Risks of Elective Cesarean Section. Deutsches Arzteblatt International, 112(29-30), 489-495. https://doi.org/10.3238/arztebl.2015.0489

NIHRD. (2018). Riset Kesehatan Dasar 2018. In National Institute of Health Reseach and Development Jakarta. https://doi.org/1 Desember 2013

Pratiwi, N. L., \& Basuki, H. (2016). Prevalensi Rasio Pelayanan Kesehatan Maternal Dan Ketersediaan Fasilitas Kesehatan Di Era Jkn / Kis Di Indonesia. Jurnal Kebijakan Kesehatan Indonesia, 05(02), 42-52.

Roudsari, R. L., Zakerihamidi, M., \& Khoei, E. M. (2015). Socio-Cultural Beliefs, Values and Traditions Regarding Women's Preferred Mode of Birth in the North of Iran. International Journal of Community Based Nursing and Midwifery, 3(3), 165-176.

Sari, P., Hapsari, D., Dharmayanti, I., \& Kusumawardani, N. (2015). Faktor-Faktor Yang Berpengaruh Terhadap Risiko Kehamilan “4 Terlalu (4-T)" Pada Wanita Usia 10-59 Tahun (Analisis Riskesdas 2010). Media Penelitian Dan Pengembangan Kesehatan, 24(3), 143-152. https://doi.org/10.22435/mpk.v24i3.3649.143-152

Sihombing, N., Saptarini, I., \& Putri, D. S. K. (2017). The Determinants of Sectio Caesarea Labor in Indonesia ( Further Analysis of Riskesdas 2013). Jurnal Kesehatan Reproduksi, 8(1), 63-75. https://doi.org/10.22435/kespro.v8i1.6641.63-75

Souza, J. P., Gülmezoglu, A. M., Lumbiganon, P., Laopaiboon, M., Carroli, G., Fawole, B., \& Ruyan, P. (2010). Caesarean section without medical indications is associated with an increased risk of adverse short-term maternal outcomes: The 2004-2008 WHO Global Survey on Maternal and Perinatal Health. BMC Medicine, 8(1), 71. https://doi.org/10.1186/1741-7015-8-71 
International Journal of Innovation, Creativity and Change. www.ijicc.net

Volume 15, Issue 9, 2021

Suryati, T. (2013). Persentase Operasi Caesaria Di Indonesia Melebihi Standard Maksimal, Apakah Sesuai Indikasi Medis? Buletin Penelitian Sistem Kesehatan, 15(4 Okt), 331338. https://doi.org/10.22435/bpsk.v15i4Okt.3031

Vega, E. S., Casto, S., Chamizo, K., Floreshernandez, D., Landini, V., \& Guillen, A. (2015). Rising Trends of Cesarean Section Worldwide: A Systematic Review. Obstetrics \& Gynecology International Journal, 3(2). https://doi.org/10.15406/ogij.2015.03.00073

WHO Statement on Cesarean Section Rates, Human Reproduction Programme 1 (2015). https://doi.org/10.1016/j.rhm.2015.07.007

Ye, J., Zhang, J., Mikolajczyk, R., Torloni, M. R., Gülmezoglu, A. M., \& Betran, A. P. (2016). Association between Rates of Caesarean Section and Maternal and Neonatal Mortality in the 21st Century: A Worldwide Population-based Ecological Study with Longitudinal Data. BJOG: An International Journal of Obstetrics and Gynaecology, 123(5), 745-753. https://doi.org/10.1111/1471-0528.13592 